\title{
Characterizing soils under different land use patterns in Terai region of West Bengal
}

\section{PAL, P.K. PATRA AND D. MUKHOPADHYAY}

Received : 17.03.2015; Revised : 09.05.2015; Accepted : 22.05.2015

\section{MEMBERS OF RESEARCH FORUM:}

Corresponding author :

D. PAL, Department of Environmental Studies, Sikshsa-

Bhavana, Visva Bharati,

SANTINIKETAN (W.B.) INDIA

Email: dip_anod@ rediffmail.com

\section{Co-authors :}

P.K. PATRA, Department of Environmental Studies, SikshsaBhavana, Visva Bharati, SANTINIKETAN (W.B.) INDIA

Email: pulakpatra@ visva-bharati.ac.in

D. MUKHOPADHYAY, Department of Soil Science and Agricultural Chemistry, Uttar Banga Krishi Viswavidyalaya Pundibari, $\mathrm{COOCH}$ BEHAR (W.B.) INDIA

Email: dibsm107@gmail.com

\section{Summary}

A study under four different eco-systems (forest land, agricultural land, tea garden and fallow land) was conducted under Terai situation of West Bengal to characterise the soils with important physico-chemical properties and also to find out the available nutrient status in soils with the increasing depth. It was observed that the available N-P-K of the soils and the exchangeable $\left(\mathrm{Ca}^{+2}+\mathrm{Mg}^{+2}\right)$, electrical conductivity (EC), oxidisable organic carbon (OC) and total C-H-N-S in soil significantly varied with the depth of soils in most of the cases. The soils were acidic in reaction and non-saline in character. The available N-P-K and OC of soils of forest, agricultural and tea-garden differed with the uncultivated fallow. The survey of the regions showed that the buildup of nutrients $\left(\mathrm{N}-\mathrm{P}-\mathrm{K}, \mathrm{Ca}^{+2}+\mathrm{Mg}^{+2}\right)$ varied with the changing ecosystems as reflected by the $\mathrm{C} / \mathrm{N}, \mathrm{C} / \mathrm{S}$ and $\mathrm{C} / \mathrm{H}$ ratio of the soils.

Key words : Ecosystem, Nutrients, Physico-chemical

How to cite this article : Pal, D., Patra, P.K. and Mukhopadhyay, D. (2015). Characterizing soils under different land use patterns in Terai region of West Bengal. Asian J. Soil Sci., 10(1) : 142-148. 